\section{Post-thrombotic syndrome in the Middle Age}

\section{Paolo Zamboni}

Vascular Diseases Center, University of Ferrara, Italy

Post-thrombotic syndrome (PTS) is a disabling disease, which often leads to chronic venous leg ulceration. It can be treated and/or prevented after deep vein thrombosis (DVT) by the use of elastic stockings, because surgery is a highly selected option. Symptoms and complications of PTS appear several years after DVT. While varicose veins and ulcerations were extensively described in antique art and literature, the first medical case truly compatible with a PTS story was depicted in the manuscript of Guillaume de Saint-Pathus, in the Middle Age.

The manuscript titled La vie et les miracles de Saint Louis ${ }^{1}$ tells us that in 1271 Raoul, a 20year-old young man, suffered from a monolateral acute edema in the right calf. Some days later, the swelling extended up to the thigh (Figure 1A). He was a Norman shoemaker and underwent to a medical consult. In 1271 Raoul's phlebologist was Henri de Perche. This confirms us that French physicians were absolute beginners in phlebology. Henri suggested him to lie supine, as well as to wait and see. What happened some months later, with big surprise of Raoul and his relatives, was the disappearance of the swelling (Figure 1B). For some years the leg was slim and he resumed to work. However, some years later Raoul again worsened in the right lower limb, and suddenly developed an ulceration at the medial aspect of the right ankle (Figure 1C).

At that time St. Eloi's shrine was the hub center for venous leg ulceration. Raoul underwent to additional unspecified treatment attempts, but everything was unsuccessful. The last hope was to visit the tomb of King Saint Louis, where Raoul spent days after days in praying the saint. Finally, he collected the dust found below the stone covering the tomb, and applied it directly to the ulcer. This was not the first description of an advanced dressing for venous leg ulcer. In the Bassi library, Glauco Bassi's typewritten notes report other previous descriptions, starting from the Bible. ${ }^{2}$ However, the manuscript reports that the wound miraculously healed. We do not know about the big problem of ulcer recurrences in Raoul's rest of the life, as in modern PTS happens. However, it has been reported that Raoul was still alive 11 years after the Saint Louis miracle. I came curious to deepen the story of Raoul, after reading a monograph on the history of DVT. The story of Raoul was also, according to Galanaud et al., the first medical report of DVT. ${ }^{3}$ In ancient Greece, neither Hippocrates nor Oribasius, reported clinical cases resembling DVT; this is also true looking to the art of ancient Egypt, Persia, and South America. Even Roman physicians such as Galen or Caelius, did not report something suggesting a diagnosis of DVT. ${ }^{3}$ We can conclude that, to the best of our knowledge, Raoul's story is the first medical report on both DVT and PTS.

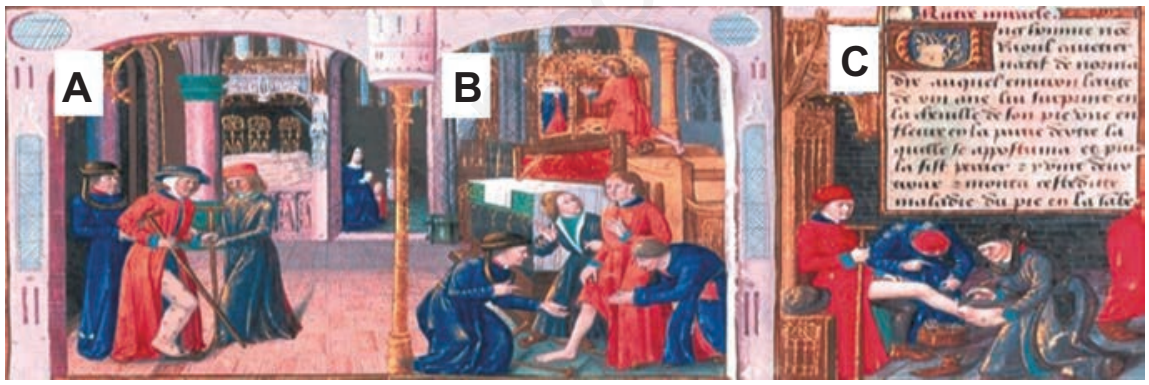

Figure 1. A) Acute lower limb edema in Raoul's lower right extremity; B) edema resolution; C) ulcer development several years later. Modified from De Saint Pathus, 1330$1340 . .^{1}$
Correspondence: Paolo Zamboni, Vascular Diseases Center, University of Ferrara, via Aldo Moro 8, 44124 Cona, Ferrara, Italy.

E-mail: paolozamboni@icloud.com

Received for publication: 22 October 2015.

Revision received: 11 December 2015.

Accepted for publication: 1 February 2016.

This work is licensed under a Creative Commons Attribution 3.0 License (by-nc 3.0).

(O) Copyright P. Zamboni, 2015

Licensee PAGEPress, Italy

Veins and Lymphatics 2015; 4:5600

doi:10.4081/vl.2015.5600

\section{References}

1. De Saint Pathus G. La vie et les Miracles de Saint Louis. Paris: Bibliothèque National de France; 1330-1340.

2. Bresadola M. The Bassi Historical International Library of Phlebology at the Ferrara University Hospital. Veins and Lymphatics 2014;3:4150.

3. Galanaud JP, Laroche JP, Righini M. The history and historical treatments of deep vein thrombosis. Thromb Haemost 2013;11:402-11. 